\title{
The Psychological and Cognitive Processes Underlying College Students' Demotivation to Learn English
}

\author{
Xiaobin Ren \\ Graduate School of Language and Communication, National Institute of Development Administration, Bangkok, \\ Thailand \\ M.L. Jirapa Abhakorn \\ Graduate School of Language and Communication, National Institute of Development Administration, Bangkok, \\ Thailand
}

\begin{abstract}
This study aims to construct a model to explain Chinese college students' psychological and cognitive processes underlying their demotivation to learn English. Grounded theory method and cognitive maps were creatively combined to analyze the interview data from 21 college students in China's universities. This study found three paths underlying students' demotivation to learn English: 1) the large discrepancy between students' actual selves and their possible selves might firstly produce motivation for a short period but then could cause low self-efficacy and negative affects. The large discrepancies might also directly generate negative affects among college students; those different negative affects could lead to demotivation of English learning. 2) college students' low ought-to selves could cause their low ideal selves and then demotivation of English learning; 3) demotivation to learn English might also associate with low value of English learning in college students' minds. At the end of this research, some pedagogical implications are given based on those findings.
\end{abstract}

Index Terms - demotivation, psychological and cognitive processes, English learning, grounded theory

\section{INTRODUCTION}

Motivation for language learning among students is a lasting topic among researchers, and numerous influential theories of motivation have been proposed in the field of second language acquisition (SLA) (e.g., Dörnyei, 2009; Gardner \& Lambert, 1959). As the dark side of motivation, demotivation means gradually decreasing investment in the process of English learning among college students in this study (definition drawn from Clare, Renandya, \& Rong, 2019; Dörnyei \& Ushioda, 2011; W. Zhang, 2016, etc.). This phenomenon also deserves research and has gradually drawn SLA researchers' attention in recent years. Falout, Elwood, and Hood (2009) thought EFL language learners' demotivation could cause a series of problems, including students' negative attitudes and undesirable behaviors, reduced class activity dynamics, decreased English teachers' motivation, and students' long-term unfavorable learning results. Therefore, Sakai and Kikuchi (2009, pp. 57-58), (Ghadirzadeh, Hashtroudi, \& Shokri, 2012, p. 189), Boonchuayrod (2019), and Wang and Guan (2020, pp. 859-860) thought more demotivational studies of English learning should be conducted to help English teachers to solve students' demotivational problems and therefore improve their teaching quality. Moreover, demotivation to learn English among college students in many EFL countries is not a rare phenomenon (e.g., see, Boonchuayrod, 2019; S. Kim, 2015; Sakai \& Kikuchi, 2009; Trang \& Baldauf, 2007). For example, numerous college students in China suffer from demotivation of English learning after they enter universities (Li, 2021; Li \& Zhou, 2017). This problem poses a challenge for a great number of English teachers and learners there. From this perspective, demotivational studies should also be conducted to better understand this problem and to help EFL teachers and students in their English teaching and learning.

Currently, some studies have been conducted to investigate students' demotivation. However, some problems can be found in them. For example, although some studies explored the internal reasons for students' demotivation, those psychological and cognitive factors found in several existing studies seem scattered and independent from each other. Besides, demotivation of English learning is more frequently treated as a fixed result rather than a dynamic process in current studies. This study aims to narrow those research gaps and to construct a grounded theory model to explain the psychological and cognitive processes underlying Chinese college students' demotivation to learn English.

\section{LITERATURE REVIEW}

Numerous studies have been conducted to investigate external factors resulting in students' demotivation of learning English (e.g., Muhonen, 2004; Sakai \& Kikuchi, 2009) and remarkable results have been achieved. For example, 
teacher-related factors (e.g., their teaching competence, skills) (e.g., Akay, 2017; Sakai \& Kikuchi, 2009; Wang \& Guan, 2020), teaching contents and materials (e.g., Li \& Zhou, 2017), class characteristics and environment (e.g., Çankaya, 2018; T.-Y. Kim, Kim, \& Kim, 2018) have been frequently mentioned. Apart from those external factors, students' internal factors for their demotivation to learn English have also attracted some researchers' attention. For example, besides English teacher related factors, Trang and Baldauf (2007) also found students' past learning experience, attitudes to English learning, and their self-esteem could be the potential demotivators. Ghadirzadeh et al. (2012) agreed that students' internal factors should not be ignored in the investigation of demotivation of English learning. They found that apart from the external factors, those internal factors, including lack of perceived individual competence and intrinsic motivation could be the demotivators among Iranian students. In addition, Sakai and Kikuchi (2009, p. 61) also found students' failure experience of English learning could also be one of the potential reasons for demotivation. However, although some studies found people's some internal factors are the potential reasons for students' demotivation to learn English, those internal factors are scattered and not systematic. Little research has been conducted to explore the relations among those factors and systematically link those different internal factors causing demotivation of English learning. This may be problematic considering that people's psychological and cognitive processes are often interrelated with each other (del Bosque \& Martín, 2008; Su \& Shum, 2019). In addition, students' demotivation to learn English is a dynamic process (Oxford, 1998; Trang \& Baldauf, 2007), in which students' demotivational levels may fluctuate. This means those English learners' psychology or cognition related with English learning may have some changes in the process of being demotivated. However, demotivation of English learning was rarely treated as a dynamic process, but rather students' demotivation was more frequently regarded as a changeless final result in current studies (Zhou \& Zhang, 2018). Therefore, the interrelations among the underlying psychology and cognition in the process of demotivation of English learning should be explored, and studies treating demotivation of English learning as a dynamic process should be conducted.

Considering the problems in current studies, this study treats demotivation of English learning as a dynamic process and has constructed a model to demonstrate the relations among students' psychological and cognitive processes underlying their demotivation to learn English.

\section{METHOD}

\section{A. Instrumentation}

In this study, semi-structured interviews were conducted among college students in mainland China's universities. To make the interview more efficient and effective, an interview guideline was designed firstly. After the initial version of the guideline was designed, peer examinations (Merriam \& Tisdell, 2015, p. 249) were conducted. Two English teaching researchers (both with a doctoral degree in English teaching) were invited to evaluate the validity of the potential questions. The interview guideline questions were revised based on the suggestions from the two experts accordingly. After that, a mock interview was conducted to check whether the potential questions in the guideline could efficiently elicit desired answers from college students. The mock interview showed that the guideline questions were appropriate for the present study. In the end, an interview guideline with 8 questions was formulated. Those guideline questions could be found from Appendix 1.

\section{B. Students Sampling and Data Collection}

Theoretical sampling method (Corbin \& Strauss, 2014; Strauss \& Corbin, 1998) was used to choose participants for this study. Theoretical sampling is a process in which the researchers or analysts collect, code, and analyze data firstly and then decide what data to collect next and where to find them. The theoretical sampling process should not end until the data is saturated (Corbin \& Strauss, 2014, p. 150; Glaser \& Strauss, 1967, p. 45). According to the rules of theoretical sampling, the researchers one-on-one interviewed 21 students (see Table 1) from universities in mainland China based on the guideline questions (see Appendix 1) before the data was saturated. Before interviewing each participant, a confidentiality agreement was given to them. All the interviews were permitted to be recorded. The interview audios were transcribed into Chinese texts through https://www.iflyrec.com/, and those texts were proofread by the researchers after each interview. 
TABLE 1

THE INFORMATION OF THE INTERVIEWEES

\begin{tabular}{|c|c|c|c|c|c|c|}
\hline $\begin{array}{l}\text { Student } \\
\text { code }\end{array}$ & Gender & $\begin{array}{l}\text { Grade } \\
\text { (year) }\end{array}$ & Major & University & Interview way & Interview time \\
\hline $\mathrm{CXD}$ & Male & Fourth & Geomatics Engineering & LIT & Online & $12 / 04 / 2021$ \\
\hline CJW & Male & First & Civil Engineering & XYNU & Face-to-face & $16 / 04 / 2021$ \\
\hline LYY & Female & Second & Business English & TJFSU & Online & $19 / 04 / 2021$ \\
\hline HQY & Female & Second & Translation & LIT & Online & $20 / 04 / 2021$ \\
\hline TYX & Male & Third & $\begin{array}{l}\text { Power Supply \& Distribution } \\
\text { Engineering }\end{array}$ & LIT & Online & $21 / 04 / 2021$ \\
\hline LY & Female & Third & Translation & XYU & Face-to-face & $21 / 04 / 2021$ \\
\hline HYQ & Male & First & Computer Science & CSU & Online & $22 / 04 / 2021$ \\
\hline HMZ & Male & First & Electronic Information & HUST & Online & $22 / 04 / 2021$ \\
\hline YYX & Female & Fourth & Management & HUST & Online & $24 / 04 / 2021$ \\
\hline DHY & Male & Second & Film production & HBBC & Face-to-face & $27 / 04 / 2021$ \\
\hline DX & Female & Third & Digital media & HBBC & Face-to-face & $28 / 04 / 2021$ \\
\hline ZLB & Female & First & Logistics engineering & HBJC & Face-to-face & $28 / 04 / 2021$ \\
\hline ZKF & Male & Second & Music & HBYC & Face-to-face & $30 / 04 / 2021$ \\
\hline GKT & Male & Third & Arts & HIFA & Online & $03 / 05 / 2021$ \\
\hline GFR & Male & First & Preschool Education & HBBC & Face-to-face & $04 / 05 / 2021$ \\
\hline RDN & Female & Second & Landscape architecture & WIT & Face-to-face & $06 / 05 / 2021$ \\
\hline PKW & Female & First & Automobile engineering & WIT & Face-to-face & $07 / 05 / 2021$ \\
\hline TDG & Female & Fourth & Preschool education & WIT & Face-to-face & $09 / 05 / 2021$ \\
\hline YJL & Female & Second & Logistics engineering & WIT & Face-to-face & $10 / 05 / 2021$ \\
\hline JWH & Female & Third & Business English & WHU & Face-to-face & $13 / 05 / 2021$ \\
\hline HXS & Male & Fourth & Civil engineering & LIT & Online & $18 / 05 / 2021$ \\
\hline
\end{tabular}

\section{Data Analysis}

This study analyzed the data based on grounded theory method (Corbin \& Strauss, 2014). This data analysis method could be divided into three stages: open coding, axial coding, and selective coding. It should be mentioned that data analyses were not finished with one-time process of the three coding stages. In fact, the three stages of grounded theory data analysis were recurrent. In this study, data analyzers coded, compared, integrated, and categorized the data recurrently before the final grounded theory model was generated. To make the data coding process convenient and efficient, the software of NVivo was applied.

\section{Open Coding}

Open coding is to code the texts based on lines or sentences with an open mind. Through open coding, related sentences and lines were coded into different concepts, which were used to identify the properties and dimensions of categories.

After transcribing the records of the 21 interviewees, 21 files were generated, which were imported into Nvivo and then analyzed with the open coding method. Overall, 1329 nodes were identified in Nvivo. After three stages of abstraction, 14 categories were generated. Table 2 demonstrates the conceptualization and categorization processes of open coding of the 21 files. However, in the following Table 2, only some original sentences are given considering the limited space of the table and paper. 
TABLE 2

THE PROCESS OF OPEN CODING

\begin{tabular}{|c|c|c|}
\hline Transcription sentence examples & Initial conceptualization (concepts) & $\begin{array}{l}\text { Final Conceptualization } \\
\text { (categories) }\end{array}$ \\
\hline I don't think English research articles are difficult to read. I can understand the rough ideas of most of the articles. & good English reading ability & \multirow{2}{*}{ Solid language foundation } \\
\hline We can leam the vocabulary by ourselves rather than being instructed by our teachers in classes. That is time wasting. & good vocabulary learning skill & \\
\hline From primary school to now, my grammar has not been good. & bad grammar & \multirow{5}{*}{ Weak language foundation } \\
\hline My previous vocabulary was limited. & poor vocabulary & \\
\hline My pronunciation is poor. My classmates and English teachers often cannot understand what I am talking about. & poor pronunciation & \\
\hline $\begin{array}{l}\text { I did not pay attention to my listening skills in senior high. After I entered university, I could hardly understand any } \\
\text { English spoken sentences. }\end{array}$ & poor listening skills & \\
\hline My English leaming method is not good for me. & unsuitable leaming method & \\
\hline I must leam English well to further my study abroad. & leam English for overseas study & \multirow{2}{*}{ High goal } \\
\hline I should be able to communicate with my future colleagues in foreign investment companies efficiently. & future work plan & \\
\hline I don't need to challenge myself to practice difficult tasks. & difficult tasks avoidance & Low goal \\
\hline About 8,000 English words should be remembered if I want to pass College English Test-6. That's too much. & large vocabulary requirement & \multirow[b]{2}{*}{ High requirements } \\
\hline $\begin{array}{l}\text { But students in English Comer in our universities should debate or discuss in "pure English". That is too difficult for } \\
\text { me. }\end{array}$ & difficult debate or discussion & \\
\hline $\begin{array}{l}\text { Most of my classmates can pass the English exam easily at the end of semester if they review the hints given by our } \\
\text { English teachers. }\end{array}$ & easy final exams & \multirow{3}{*}{ Low requirements } \\
\hline $\begin{array}{l}\text { We have learnt almost all the grammar and a lot of vocabulary in the college English textbooks in senior high. I think } \\
\text { I can leam them by myself. }\end{array}$ & repetitive teaching contents & \\
\hline There are no speaking classes and tests in our school. & no speaking requirement & \\
\hline I felt a sense of frustration when I learnt English for a long time but did not see much progress. & frustration & \multirow{2}{*}{ Negative affects } \\
\hline I hate English and English classes. & hate English & \\
\hline When I read for more than three weeks, I still could not feel I made progress. & little progress & Undesired results \\
\hline I think I cannot have a large vocabulary because I have a "funnel" memory. & no hope of large vocabulary & Low result expectancy \\
\hline Passing CET-6 is almost impossible for me even if I try my best. & no possibility of passing CET-6 & Low ability expectancy \\
\hline We seldom use English in power supply. We use Chinese almost all the time. & power supply does not need English & \multirow{2}{*}{ Limited use opportunities } \\
\hline We don't have enough opportunities to communicate with others in English. & less use in life & \\
\hline Engineering related classes are more important than English classes. & engineering more important than English & \multirow{2}{*}{ Limited significance } \\
\hline Translation APPs are very convenient, and they can translate for us immediately. & APPs' convenience & \\
\hline I did try very hard to leam English during a period ( 2 months) when I began to prepare for PGEE. & long time spent on English grammar leaming & \multirow{2}{*}{ Motivation } \\
\hline I want to spend more time on leaming English. & English leaming intentions & \\
\hline I have given up leaming English completely. & English giving-up & \multirow{3}{*}{ Demotivation } \\
\hline I found my time spent on leaming English dropped gradually after I entered university. & less time spent & \\
\hline My passion for leaming English is always not very high. & low passion & \\
\hline
\end{tabular}

\section{Axial Coding}

Axial coding aims to develop main categories by exploring the relations among different categories and integrating related categories. In the axial coding process, 9 main categories (see table 3) were developed by comparing the 14 different categories in the open coding results and then integrating some related ones. For example, both solid language foundation and weak language foundation are about how students consider their actual English abilities. Therefore, those two categories were integrated as their English learning "actual self". Table 3 demonstrates the process of axial coding.

TABLE 3

THE PROCESS OF AXIAL CODING

\begin{tabular}{lll}
\hline Main categories & Categories & Connotation of main categories \\
\hline Actual self & $\begin{array}{l}\text { Solid Language foundation } \\
\text { Weak language foundation }\end{array}$ & $\begin{array}{l}\text { How the English learner considers his or her English } \\
\text { competence. }\end{array}$ \\
\hline \multirow{2}{*}{$\begin{array}{l}\text { Possible } \\
\text { self }\end{array}$} & $\begin{array}{l}\text { High requirements } \\
\text { Low requirements }\end{array}$ & $\begin{array}{l}\text { The attributes that the English learner believes one } \\
\text { ought to possess to meet outside expectations or to } \\
\text { avoid possible negative outcomes. }\end{array}$ \\
\cline { 2 - 3 } self & $\begin{array}{l}\text { High goal } \\
\text { Low goal }\end{array}$ & $\begin{array}{l}\text { The attributes one English learner wants to have } \\
\text { even without external influences. }\end{array}$ \\
\hline Low value & $\begin{array}{l}\text { Limited use opportunities } \\
\text { Limited significance }\end{array}$ & $\begin{array}{l}\text { Value is the worth of learning English in students' } \\
\text { minds. }\end{array}$ \\
\hline Negative affects & Negative affects & $\begin{array}{l}\text { Negative affect refers to those bad emotions, } \\
\text { feelings, moods, and attitudes. }\end{array}$ \\
\hline Low self-efficacy & $\begin{array}{l}\text { Low result expectancy } \\
\text { Low ability expectancy } \\
\text { Undesired results }\end{array}$ & $\begin{array}{l}\text { Self-efficacy means the possibility one thinks the } \\
\text { desired results or desired abilities can be achieved. }\end{array}$ \\
\hline Motivation & Motivation & $\begin{array}{l}\text { Motivation means English learners have passion and } \\
\text { persistence in learning English. }\end{array}$ \\
\hline Demotivation & Demotivation & $\begin{array}{l}\text { Misbehavior, or low investment in the process of } \\
\text { English learning. }\end{array}$ \\
\hline
\end{tabular}

\section{Selective Coding}

Selective coding aims to further integrate and refine the main categories and to choose a core category from those main categories. In this data coding stage, large actual-possible self discrepancy emerged from the existing main categories and interviewing data. In addition, the core category was found from the main categories by utilizing cognitive maps (L. Zhang, 2011). Those cognitive maps were used to demonstrate the interview details based on causes and effects among a series of remarks on a certain phenomenon and display interviewees' mental representations 
(Chaney, 2010). In this study, 21 college students were interviewed, and accordingly 21 cognitive maps were initially drawn, and then upgraded and integrated based on the results of open coding, axial coding, and the refinements of the main categories in selective coding. In the end, a comprehensive cognitive map demonstrating the relations among the core category and the other main categories was drawn.

Specifically, to get the final cognitive map demonstrating the relations among the 9 main categories, the original transcriptions of the 21 interviewees were reviewed again. Firstly, 21 cognitive maps of concepts were drawn based on the original data by applying the concepts from the open coding, and then their corresponding cognitive maps of categories and main categories were drawn based on the results of open coding and axial coding. This paper chose excerpts from 2 participants as examples to demonstrate the drawing and upgrading processes of the cognitive maps of concepts, categories, and main categories.

Table 4 displays the excerpt of CXD's interview transcription and its corresponding open coding results (concepts). Based on the excerpt, a cognitive map of concepts (figure 1) was drawn by analyzing causes and effects in the transcription data. With the open coding results in table 2, the cognitive map of categories (figure 2) was made by integrating the concepts into their corresponding categories.

TABLE 4

CXD'S INTERVIEW DATA AND OPEN CODING (TRANSLATED INTO ENGLISH)

\begin{tabular}{|c|c|}
\hline Transcription (excerpts) & Concepts \\
\hline $\begin{array}{l}\text { My demotivation to learn English is mainly from English test. After I prepared for the post- } \\
\text { graduate entrance examination (PGEE) for long time, I found the English test in PGEE was } \\
\text { still quite difficult for me. ... From primary school to now, my grammar is not good.... When } \\
\text { I meet long sentences in the reading comprehension part, I always felt a little afraid. If I made } \\
\text { too many grammatical mistakes or cannot understand the long sentences, I would feel } \\
\text { frustrated. Then, I didn't want to learn English anymore for quite a long time. } \\
\text { Yes, I did try very hard to learn English during a period ( } 2 \text { months) when I began to prepare } \\
\text { for PGEE because, you know, English is a very important subject in PGEE. If you cannot get } \\
\text { more than } 40 \text { points, you might fail the whole examination though your overall scores are } \\
\text { very high, because each individual subject has a minimum score requirement. Because my } \\
\text { grammar is not good, I have watched many related teaching videos. But I think grammar is } \\
\text { too hard for me. when I did grammar test, I still made many mistakes. I was afraid I cannot } \\
\text { pass the examination.... I avoided English learning when I have other tasks to do. } \\
\text { When English teacher spoke English too much in class, I cannot understand. Besides, our } \\
\text { English textbooks were too difficult for me. New Horizon College English textbook has too } \\
\text { much difficult words. When I read the text in the textbook, I always had a sense of failure.... } \\
\text { I seldom review the textbook after English class unless the final English test was coming. ... } \\
\text { In English class, I don't want to read the English texts. You know, sometimes our English } \\
\text { teachers picked me to read a paragraph in our class, I don't want to open my mouth to read } \\
\text { because I think my pronunciation is not standard, and some students may laugh at my } \\
\text { accent. ... I felt very embarrassed when reading the paragraphs. I hate English classes. If it is } \\
\text { possible, I won't attend English classes. }\end{array}$ & $\begin{array}{l}\text { difficult PGEE; } \\
\text { weak grammar foundation; } \\
\text { afraid and frustrated; } \\
\text { motivation declining; } \\
\text { long time spent on English } \\
\text { grammar learning; } \\
\text { weak grammar foundation; } \\
\text { little gains; afraid; no } \\
\text { possibility of passing exam; } \\
\text { motivation declining; } \\
\text { cannot understand teaching } \\
\text { contents; too difficult } \\
\text { textbooks; failure; low } \\
\text { sense of } \\
\text { motivation; } \\
\text { low motivation; } \\
\text { afraid of opening mouth in } \\
\text { class; speaking ability; } \\
\text { weak low } \\
\text { embarrassed; } \\
\text { negative attitude; } \\
\text { motivation }\end{array}$ \\
\hline
\end{tabular}

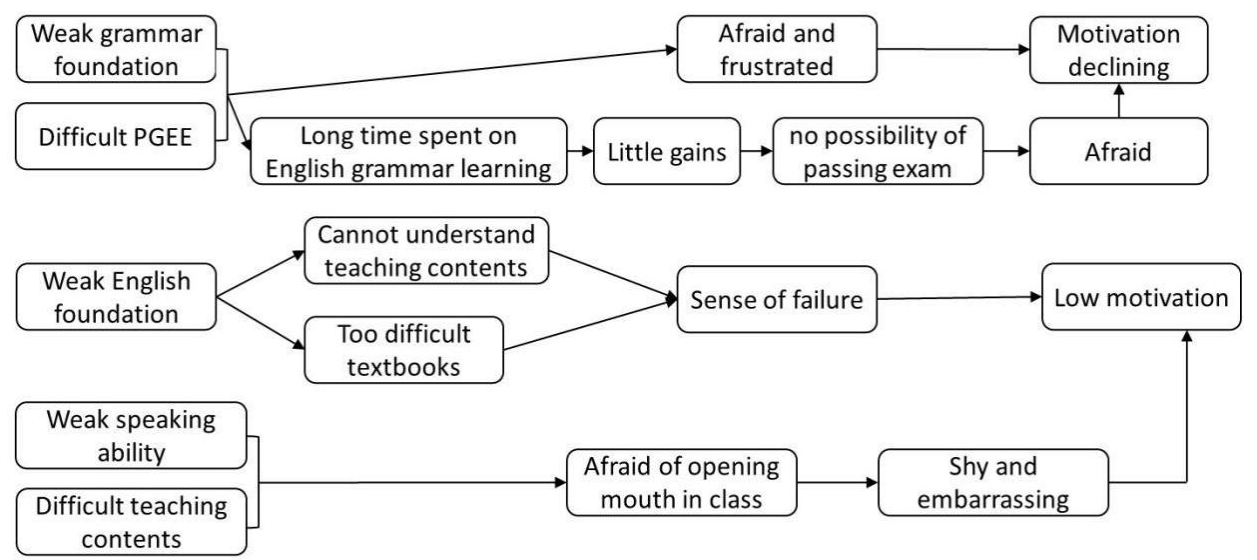

Figure 1 CXD's Cognitive Map of Concepts

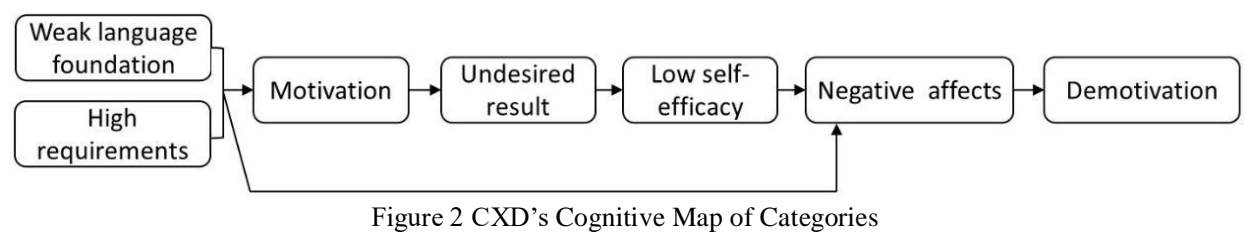

CJW's cognitive maps were drawn based on the same process as that of CXD. His cognitive map of concepts is 
demonstrated in figure 3 according to the transcription excerpt in table 5, and his cognitive map of categories was drawn based on the open coding results in table 2 and can be found in figure 4.

TABLE 5

CJW'S INTERVIEW DATA AND OPEN CODING (TRANSLATED INTO ENGLISH)

Transcription (excerpts)

Vocabulary is very important for English learning. I have tried to remember English words
through different ways. But after I entered university, I recited words from dictionary rather
than from glossary in guideline books for College English Test-4 or College English Test
(CET-4 or CET-6), because I thought if I can remember the words in the dictionary, I will
have enough vocabulary to pass CET-4 and CET-6. However, because my previous
vocabulary was poor, it took me quite a long time to remember and review those vocabulary.
I have spent a lot of time on learning and remembering those words in the dictionary, but
when I want to use them, I still cannot remember them and don't know how to use them in
writing and speaking. It made me very disappointed and frustrated, and I didn't have a sense
of achievement.
One of the most important methods is reading. But when I read every morning for more than
three weeks, I still could not feel I made progress, then I would become unconfident whether
I can improve my reading and speaking through this way. After about three weeks of reading,
I gave up reading.
We don't have enough opportunities to communicate with others in English. Sometimes, I
think learning English is only for passing examinations and getting credits. We didn't pay
much attention to English learning.
But at present, the requirements in university are very low. ... I don't need to pass CET-4 or
CET-6.... Passing English exams in the final term is enough for me to graduate. ... Many
students do not need to study hard, and they can pass English exams easily by only reviewing
the hints given by teachers only before final English exams. I think that is far from enough
for English using in the future.

for English using in the future.

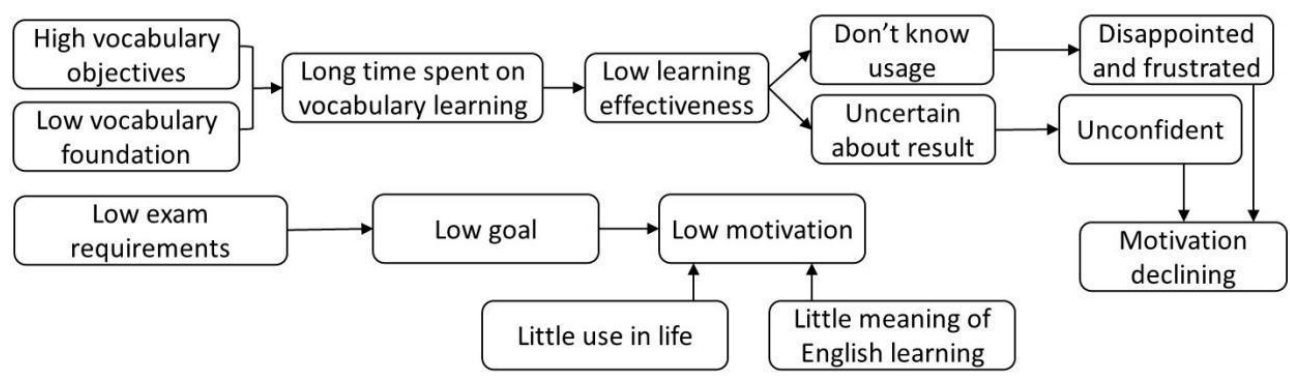

Figure 3 CJW's Cognitive Map of Concepts

high vocabulary objectives;

low vocabulary foundation;

long time spent on

vocabulary learning; low

learning effectiveness; don't

know usage; disappointed

and frustrated;

low learning effectiveness; unconfident; uncertain about result; motivation declining; little use in life;

little meaning of English

learning; low motivation;

low exam requirements in

universities;

low motivation;

low goal;

\section{Figure 3 CJW's Cognitive Map of Concepts}

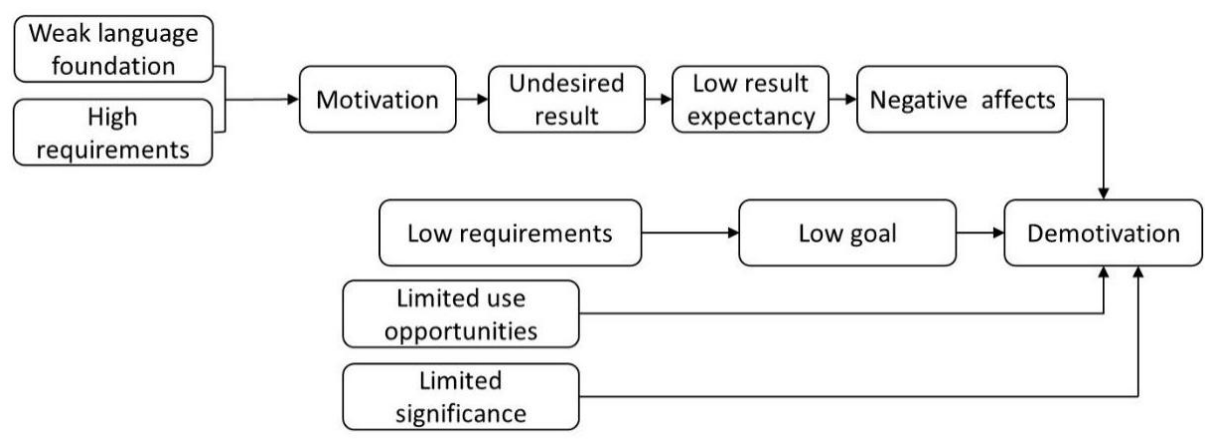

Figure 4 CJW's Cognitive Map of Categories

Based on the above-mentioned cognitive map drawing process, 21 cognitive maps of categories were drawn. The final integrated cognitive map (figure 5) was drawn by integrating the 21 cognitive maps based on open coding results. This integrated cognitive map of categories was continually abstracted based on the results of axial coding and further refinements of the main categories in selective coding, and the grounded theory model (figure 6) demonstrating students' psychological and cognitive processes underlying their demotivation to learn English was constructed in the end. 


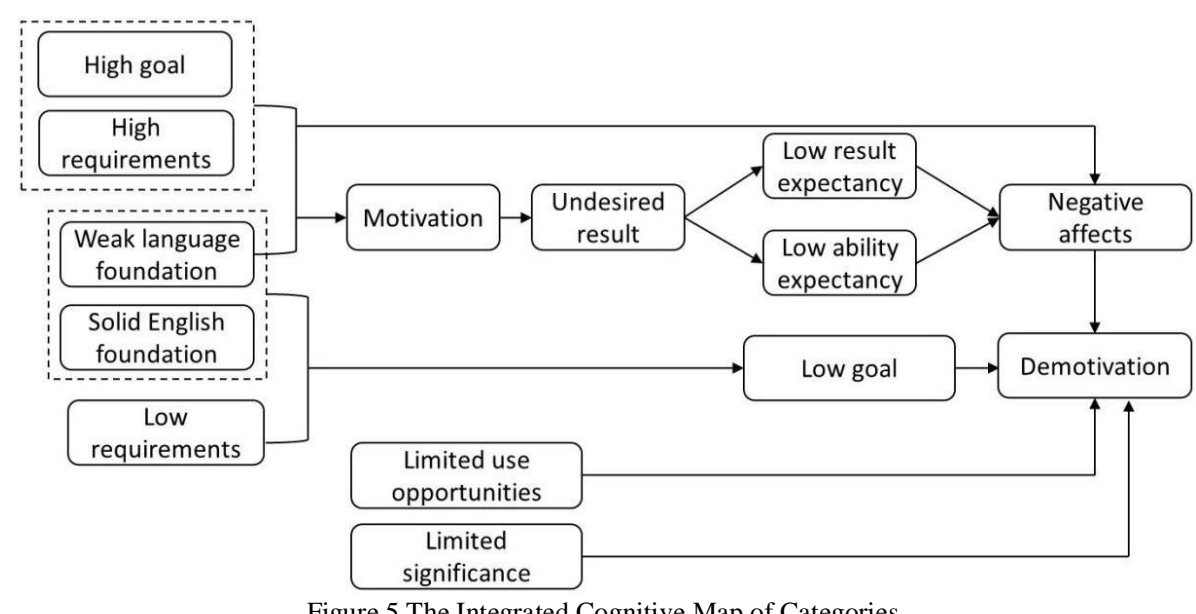

Figure 5 The Integrated Cognitive Map of Categories

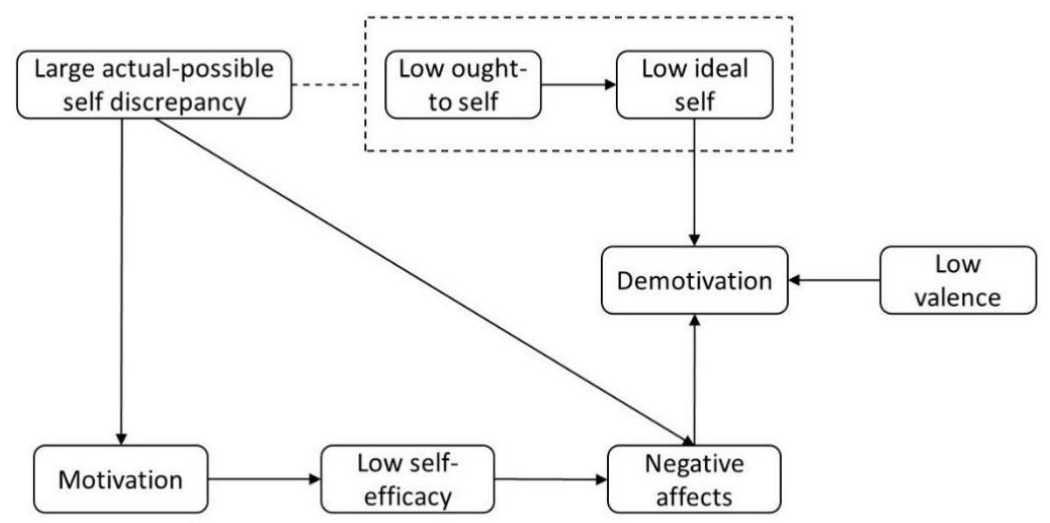

Figure 6 The Cognitive Map for College Students' Demotivation to Learn English

\section{FINDINGS}

This study explored the psychological and cognitive processes underlying college students' demotivation to learn English. Through grounded theory analysis, this study constructed a model (figure 6) to explain those underlying processes, in which demotivation could be identified as the core category, linking three paths in the model.

\section{A. From Large Actual-possible Self Discrepancy to Demotivation}

College students' actual selves in this study mean how they think of their English competences, while their possible selves, including their ought-to selves and ideal selves, mean the attributes one ought to and wants to possess as for English learning. This study found that some students' demotivation to learn English originated from the large discrepancy between their actual selves and possible selves. In the face of much pressure from the high school requirements or the high goal setting, some students firstly were motivated to learn English. However, such motivation was often temporary and short-lasting. After they motivated themselves to learn English for a short period, and found they made only little progress or even no progress, some would have low self-efficacy of English learning in their minds, which could lead to students' negative affects. They might feel frustrated, nervous, embarrassed, etc. Those negative affects usually ended with their demotivation to learn English.

In addition, large actual-possible self discrepancy among college students may also directly lead to their negative affects, and thus contribute to their declining motivation, low motivation or even no motivation. For example, the demanding tasks or activities in English classes (e.g., all-English debating) could decrease students' interest in English classes. Some may even turn negative attitudes towards English classes and their English teachers, thereby causing demotivation.

\section{B. From low Ought-to Self to Demotivation}

This path has some relations with the above one, because low ought-to self and low ideal self are the components of students' low possible selves. In this path, low ought-to selves could lead to low ideal selves of students' English learning, which may end with demotivation. According to several participants in this research, English teaching requirements in some of China's universities were relatively low for their corresponding students. For example, many English teachers tend to give their students very detailed guidelines to help college students to prepare for the final exams. Under such conditions, students often do not need to challenge themselves to set high goals, and only need to 
review the guideline-related contents before the final exams come. At other time, however, they seldom studied English but chose to learn some challenging and "difficult-to-pass" subjects.

\section{From Low Value to Demotivation}

Low value of English learning in this study means the low status or limited significance of learning English for college students. This study found that low value of English learning in students' minds may also lead to their demotivation to learn English. In many of China's universities, international students and teachers are rather rare. For some non-English majors, almost all their teachers and classmates speak Mandarin, and they almost never communicate with each other in English out of English classes. Therefore, some students may hold the opinion that English learning is only for getting credits and meeting the requirements for their graduation. Moreover, for many non-English majors, they would probably not use English anymore in their workplaces after graduation. Even if they meet some English instructions or operation manuals, they can use some cellphone APPs to scan the English texts, and the corresponding Chinese translations will appear almost immediately. Hence, the significance of learning English is quite limited for them, thus leading to their demotivation to learn English.

\section{DISCUSSION}

From the model constructed, it can be found that both very high requirements and very low requirements for English learning may be the potential origins for students' demotivation of English learning. These findings are in line with the “ $i+1$ " hypothesis (Krashen, 1991). Krashen claimed that comprehensible input is an essential environmental ingredient for language acquisition. It not only means that input should be comprehensible for the acquirers, but also needs to contain " $i+1$ ". The concept of " $i+1$ " is a metaphor, among which " $i$ " means the aspects of language already acquired, while " 1 " represents the level of language beyond learners" ability but which they are ready to acquire. Comprehensive input indicates that the requirements of English teaching for language learners should be above learners' current ability, but still within a certain degree of difficulty. In other words, if the input contains " $i+2$ " (i.e., the complexity of the input or the requirement is far beyond learners' current English competence), or " $\mathrm{i}+0$ " (i.e., the complexity of the input is the same as learners' current English competence), the acquisition effectiveness will be limited (Cheng, 2011, p. 62). However, " $i+1$ " hypothesis only indicates that very high requirements and far too low requirements of English learning in universities may negatively influence students' English learning results. Krashen did not mention students' underlying psychology and cognition related to such different requirements. How students' psychology and cognition change when teachers violate the " $\mathrm{i}+1$ " rule are not elaborated. But the grounded theory model constructed in this research linked those external requirements with students' psychology and cognition.

In the grounded theory model, large actual-possible self discrepancies could directly lead to negative affects. These findings have similarities with the self-discrepancy theory proposed by Higgins (1987). According to Higgins, Bond, Klein, and Strauman (1986), predominant discrepancies between actual self and ought-to self or ideal self could lead to different emotional vulnerability. This study found some students, when confronted with high English teaching requirements, tended to be very stressful and anxious. In addition, some students' high goals (e.g., passing Test for English Majors (TEM), getting high scores in IELTS test) could also be the potential sources for their anxiety and stress.

This study found the low value of English learning in students' minds could directly contribute to their demotivation behaviors, which partly lends support to expectancy theory (Vroom, 1964). According to expectancy theory, people's motivation level equals the product of value multiplied by expectancy (Vroom, 1964, p. 14). Value - also called valence (Oxford \& Shearin, 1994, p. 18), means the significance, attractiveness, or needs of achieving one person's goals. In this study, some students' English motivation decreased when they found English has little use (i.e., low value) in their daily life and workplaces at present and in the future.

\section{IMPLICATIONS}

This study investigated Chinese college students' psychological and cognitive processes underlying their demotivation to learn English and found three paths causing their demotivation. The three paths in the theoretical model afford us some implications.

College English teachers should deliberate on making specific teaching requirements for students to help them construct appropriate L2 ought-to selves. The popularity of the grammar-translation teaching method in China (Du, 2021) causes low speaking and listening competences among numerous college students. Therefore, when English teachers are designing activities for English classes, they should be very prudent to make the English requirements of those activities suitable for students. For example, "all-English" discussions, debates, and explanations should be avoided for students with limited speaking and listening competences. This could help to decrease students' ought-to self of English speaking and listening and therefore narrow the gap between actual and possible self. In addition, several interviewed college students in top universities universally admitted that the point of grammar and vocabulary teaching in their English classes was limited because they had learnt most of those grammatical points in their senior highs. For the vocabulary, many of them thought they could "accumulate vocabulary" outside English classes by themselves. Hence, English teachers in those high-ranking universities could heighten the complexity of the teaching contents in 
terms of grammar and vocabulary or even shift the focus to the teaching of speaking and listening. Another important factor contributing to students' demotivation of English is the relatively low requirement of the final English tests. Five students in the interviewees mentioned advanced mathematics, or physics were difficult, and they were very likely to fail the final tests of the two subjects if they did not study hard. Therefore, they have high motivation to learn those subjects. While English teachers often gave some "hints" or review guidelines for the final tests, which reduced the test difficulty. Hence, students chose to learn English only before the final English test by reviewing the detailed guidelinerelated contents. Given this, review guidelines should be avoided, and the difficulty of final English tests may need improving in some universities. These measures will urge students to construct higher ought-to selves, thus contributing to the avoidance of demotivation.

English learners should construct appropriate L2 ideal selves by setting reasonable language learning goals. Goals which are too high may motivate English learners for a short period but may gradually be an obstacle and hence end with demotivation. Furthermore, excessive goals sometimes may not lead to motivation at all, but produce nervousness, and other negative affects, and eventually demotivation to learn English. This means that English learners should construct appropriate L2 ideal selves. For example, English learners could divide their big goals into small ones and achieve those small goals step by step. For students who want to pass a challenging test (e.g., IELTS or TEM), they had better make a long plan rather than preparing shortly before the test.

The other implication is that more opportunities should be provided for students to communicate in English to increase the value of English learning in their cognition. According to Vroom (1964), the value of a task is one of the important foundations for people's motivation. If students think English can be used in their daily life or in their future career, the task of English learning could gain more value in students' minds, thus helping to overcome their demotivation. Therefore, China's universities are suggested to accept more students and teachers from international communities and hold more activities to create chances of using English among students. As for non-English majors, interns or other opportunities could be provided to students to practice English in international companies or workplaces. This will contribute to improving the value of English in future careers in students' minds.

\section{APPENDIX 1}

(translated into English)

\section{Guideline questions for the semi-structured interview}

1. After you entered university, have you ever experienced demotivation to learn English?

2. When you began your study in the university, how was your motivation for learning English and how is it now?

3. Could you tell me, in detail, about your recent experience of English learning?

4. Could you describe the whole process of your declining motivation for studying English after you entered university?

5. What do you think were the factors leading to your demotivation to learn English?

6. Could you explain how those factors could lead to your demotivation of English learning?

7. Do you have other feelings, emotions, or ideas during your demotivated period of English learning that you want to make up?

8. Do you have some advice for college students to overcome their demotivation for learning English?

\section{REFERENCES}

[1] Akay, C. (2017). Turkish High School Students' English Demotivation and Their Seeking for Remotivation: A Mixed Method Research. English Language Teaching, 10(8), 107-122.

[2] Boonchuayrod, P. (2019). Demotivation, Personality Traits, and EFL Achievement: An Exploratory Study. (Doctoral dissertation). National Institute of Development Administration, Bangkok, Thailand.

[3] Çankaya, P. (2018). Demotivation factors in foreign language learning. Journal of Foreign Language Education and Technology, 3(1), 1-17.

[4] Chaney, D. (2010). Analyzing mental representations: The contribution of cognitive maps. Recherche et Applications en Marketing (English Edition), 25(2), 93-115. doi:10.1177/205157071002500205

[5] Cheng, X. (2011). Empirical study on language features and the selection of bilingual instruction models. Foreign Languages and Their Teaching (2), 62-65. doi:10.13458/j.cnki.flatt.000359

[6] Clare, C. M. Y., Renandya, W. A., \& Rong, N. Q. (2019). Demotivation in L2 classrooms: Teacher and learner factors. LEARN Journal: Language Education and Acquisition Research Network, 12(2), 64-75.

[7] Corbin, J., \& Strauss, A. (2014). Basics of qualitative research: Techniques and procedures for developing grounded theory. California: Sage publications.

[8] del Bosque, I. R., \& Martín, H. S. (2008). Tourist satisfaction: a cognitive-affective model. Annals of Tourism Research, 35(2), 551-573. doi: https://doi.org/10.1016/j.annals.2008.02.006

[9] Dörnyei, Z. (2009). The L2 motivational self system. In Z. Dörnyei \& E. Ushioda (Eds.), Motivation, language identity and the L2 self (pp. 9-42). Bristol, UK: Multilingual Matters.

[10] Dörnyei, Z., \& Ushioda, E. (2011). Teaching and Researching Motivation (2nd ed.). Harlow, United Kingdom: Pearson.

[11] Du, Y. (2021). Grammar Translation and its Use in Present-day China. Journal of Arts and Humanities, 10(05), 28-35.

[12] Falout, J., Elwood, J., \& Hood, M. (2009). Demotivation: Affective states and learning outcomes. System, 37(3), 403-417. doi: 
https://doi.org/10.1016/j.system.2009.03.004

[13] Gardner, R. C., \& Lambert, W. E. (1959). Motivational variables in second-language acquisition. Canadian Journal of Psychology/Revue canadienne de psychologie, 13(4), 266-272. doi:10.1037/h0083787

[14] Ghadirzadeh, R., Hashtroudi, F. P., \& Shokri, O. (2012). Demotivating factors for English language learning among university students. Journal of Social Sciences, 8(2), 189-195.

[15] Glaser, B. G., \& Strauss, A. (1967). The discovery of grounded theory: Strategies for qualitative research. Chicago: Aldine: Taylor \& Francis.

[16] Higgins, E. T. (1987). Self-discrepancy: A theory relating self and affect. Psychological Review, 94(3), 319-340. doi:10.1037/0033-295X.94.3.319

[17] Higgins, E. T., Bond, R. N., Klein, R., \& Strauman, T. (1986). Self-discrepancies and emotional vulnerability: How magnitude, accessibility, and type of discrepancy influence affect. Journal of Personality and Social Psychology, 51(1), 5-15. doi:10.1037/0022-3514.51.1.5

[18] Kim, S. (2015). Demotivation and L2 motivational self of Korean college students. English Teaching, 70(1), 29-55.

[19] Kim, T.-Y., Kim, Y., \& Kim, J.-Y. (2018). A Qualitative Inquiry on EFL Learning Demotivation and Resilience: A Study of Primary and Secondary EFL Students in South Korea. The Asia-Pacific Education Researcher, 27(1), 55-64. doi:10.1007/s40299-017-0365-y

[20] Krashen, S. (1991). The input hypothesis: An update. In J. E. Alatis (Ed.), Linguistics and language pedagogy: The state of the art (pp. 409-431). Washington, DC: Georgetown University Press.

[21] Li, C. (2021). Understanding L2 Demotivation Among Chinese Tertiary EFL Learners From an Activity Theory Perspective. Frontiers in psychology, 12, 704430-704430. doi:10.3389/fpsyg.2021.704430

[22] Li, C., \& Zhou, T. (2017). A Questionnaire-Based Study on Chinese University Students' Demotivation to Learn English. English Language Teaching, 10(3), 128-135.

[23] Merriam, S. B., \& Tisdell, E. J. (2015). Qualitative research: A guide to design and implementation. CA: Jossey-Bass.

[24] Muhonen, J. (2004). Second language demotivation: Factors that discourage pupils from learning the English language. University of Jyvaskyla, Finland.

[25] Oxford, R. (1998). The unravelling tapestry: Teacher and course characteristics associated with demotivation in the language classroom. Demotivation in foreign language learning. Paper presented at the TESOL'98 Congress, Seattle.

[26] Oxford, R., \& Shearin, J. (1994). Language learning motivation: Expanding the theoretical framework. The Modern Language Journal, 78(1), 12-28. doi:10.2307/329249

[27] Sakai, H., \& Kikuchi, K. (2009). An analysis of demotivators in the EFL classroom. System, 37(1), 57-69. doi: https://doi.org/10.1016/j.system.2008.09.005

[28] Strauss, A., \& Corbin, J. (1998). Basics of Qualitative Research Techniques: Techniques and Procedures for Developing Grounded Theory (2nd ed.). CA: Sage Publications.

[29] Su, M. R., \& Shum, K. K.-m. (2019). The moderating effect of mindfulness on the mediated relation between critical thinking and psychological distress via cognitive distortions among adolescents. Frontiers in Psychology, 10, 1-11. doi:10.3389/fpsyg.2019.01455

[30] Trang, T. T. T., \& Baldauf, R. B. (2007). Demotivation: Understanding resistance to English language learning-the case of Vietnamese students. The journal of Asia TEFL, 4(1), 79-105.

[31] Vroom, V. H. (1964). Work and Motivation. Oxford, England: Wiley.

[32] Wang, Y., \& Guan, H. (2020). Exploring demotivation factors of Chinese learners of English as a foreign language based on positive psychology. Revista Argentina de Clínica Psicológica, 29(1), 851-861.

[33] Zhang, L. (2011). The expression and sharing of tacit knowledge based on cognitive map. Wuhan, China: Wuhan University Press.

[34] Zhang, W. (2016). Research on Chinese learning demotivation of overseas students in China. (Ph.D). East China Normal University, Shanghai, China.

[35] Zhou, D., \& Zhang, H. (2018). A bibliometric analysis of English learning demotivation of Chinese learners. Journal of Shenyang Agricultural University (Social Sciences Edition), 20(1), 89-94. doi:10.3969/j.is s n.1008- 9713.2018.01.018

Xiaobin Ren is currently a PhD candidate in National Institute of Development Administration, Bangkok, Thailand. He is also working as an English teacher in Hubei Business College, Wuhan, China. His research interests include EFL teaching and English teacher education.

Jirapa Abhakorn is an assistant professor at Graduate School of Language and Communication, National Institute of Development Administration, Thailand. She obtained her Doctorate Degree in Education, Communication and Applied Linguistics from Newcastle University, UK. Her arears of interests include English language teaching, English language education policy, language teacher training and language classroom interaction. Some of her notable works include the study of classroom interaction and thinking skill development, pedagogical functions of teacher talk, English language curriculum design and development, and English language teacher professional development. 